\title{
History and Engagement in the Work of Bezerra de Menezes
}

\section{Marcelo Alves de Paula Lima*}

\begin{abstract}
The purpose of this article is to analyse the works of Adolpho Justo Bezerra de Menezes (1910-2006), one of the first Brazilian diplomats to serve in Indonesia, and an enthusiast of Brazilian rapprochement towards the Afro-Asian world. In his books, historical interpretation is closely tied to political engagement, and he turns to the past in order to legitimise a greater role for Brazil in the Third World. His ideas also interact with the context in which they were written; they express the bipolarity of the Cold War, but also advocate change. Many of these ideas were later incorporated into Brazilian diplomacy.
\end{abstract}

Keywords: Bezerra de Menezes; Brazilian diplomacy; independent foreign policy; non-alignment; Cold War; Afro-Asian.

\section{Introduction}

The purpose of this paper is to analyse the works of Adolpho Justo Bezerra de Menezes, ${ }^{1}$ one of the first Brazilian diplomats to serve in Indonesia, and an advocate of close relations between Brazil and the Afro-Asian world. These include O Brasil e o Mundo Ásio-Africano (Brazil and the Asian-African World, 1956, although we analyse an edition of 2012), Ásia, África e a Politica Independente do Brasil (Asia, Africa and the Independent Policy of Brazil, 1961), Subdesenvolvimento e Politica Internacional (Underdevelopment and International Politics, 1963) and Um Diplomata no Oriente (A Diplomat in the East, 1997).

These works provide us with insights that enhance the debate about Brazil's relations with the Western world. A recent article in the Brazilian media (Rodarte 2018) discusses the extent to which this country can be regarded as part of the West. Although Brazilians widely identify themselves as Westerners, this is still an issue in Western Europe and the USA. Despite European colonisation and its cultural heritage, Brazil's recent history, including military regimes and periods of underdevelopment, continue to exclude it from the 'Western Club.' Nevertheless, Brazil's ambiguous position in the 'East versus West' dilemma may be beneficial because this allows it to engage with Western powers while interacting with and even leading non-Western countries as well.

* Federal University of Minas Gerais (UFMG), Belo Horizonte-MG, Brazil; marceloapl@yahoo.com.br. ORCID iD 0000-0002-8993-0858. 
This debate is not new. It developed throughout the 1950s and the 1960s as Brazil sought to establish relations with the recently emancipated countries in the Afro-Asian world. Therefore, this article relates to the discussions about the ideas that helped to justify Brazilian relations with Africa and Asia in the post-1945 world. Menezes was aware of that debate and used his historical knowledge and diplomatic position to contribute to it. In trying to show Brazil as a bulwark of a reshaped West as well as an important partner and leader of the Third World, he also demonstrated how history can be instrumentalised for political purposes. His books give us a better understanding of the ideas that fostered Brazilian rapprochement with the Third World since the Jânio Quadros government in 1961. This also chimes with Contexto's focus, as it deals with issues of the Global South in a historical context.

According to Mapa (2016: 27-28), Menezes was 'one of the first Brazilian diplomats to think in terms of a political action in accordance with the national interest and pragmatic towards the Afro-Asian world.' Situated in an intelligentsia and political establishment characterised by 'Europeanism in terms of culture, or Americanism in terms of economic and commercial interests, he asserted that Brazil should not fear assuming a position as an underdeveloped country. He pleaded for a new diplomatic political culture, one more committed to underdeveloped countries. Instead of considering Brazil as a champion of capitalism, he proposed the new idea of the West as neither communist nor capitalist, and free from the opportunism of the superpowers.

He regarded closer relations with Asia and Africa as beneficial not only because it improved Brazil's international presence, but also its profits. In a world divided by the Cold War, he believed the North-South conflict was far more important than the EastWest one (Mapa 2016: 23-26).

Menezes was part of a new generation of Brazilian diplomats who emerged after 1945 , following the foundation of the Rio Branco Institute. This paved the way for a politically engaged diplomatic staff, willing to play a major role in foreign policy-making and to provide diplomacy with meaningful content.

These new diplomats were no longer satisfied by merely fulfilling their bureaucratic obligations (Alves and Viana 2014: 691). Given this, we need to acknowledge the importance for this analysis of historians such as Jörn Rüsen and Pierre Rosanvallon, to whom the interpretation of the past is inseparable from political engagement and aspirations. Diplomatic activity and an understanding of the past work together in Menezes's books in a remarkable way, since he uses the past to legitimise political decisions in the present.

His ideas were in line with Brazilian foreign policy in the 1960s. From the start of the $20^{\text {th }}$ century until the 1960 s, Brazilian diplomacy was subservient to Washington. Then, however, Brazil began to challenge this position and search for new global partners, including newly independent nations (Rodrigues 1966: 35-36, 71). The short term of President Jânio Quadros in 1961 laid the grounds for the 'independent foreign policy' (IFP) through which Brazil sought to transcend the narrow limits of its diplomacy.

The IFP can only be understood within the framework of the Cold War. In 1955, Indonesia hosted the Bandung Conference, which brought together leaders of numerous Asian and African countries, many of which had just achieved independence. Bandung 
was one of the first events that 'gave Asia a voice' in international matters. Its most important principles were non-alignment with the two Cold War superpowers, and Afro-Asian solidarity (Mackie 2005). Menezes was an observer at the conference and was dazzled by the new world he saw arising at Bandung. In his view, Brazil should not stand idly by while this new world unfolded. Therefore, he began to encourage Brazil to pursue an independent foreign policy, which would enable it to join forces with these new nations.

In the sections that follow, I approach the author's books chronologically so that we can grasp their continuities and discontinuities. This will allow us to understand how the author interpreted the international scene and Brazil's insertion into it, as well as his projects and aspirations, and how his writing interacted with the context in which they emerged. Next, I explore how his ideas were connected to Brazilian foreign policy and to other ideas of his time. The last section synthesises the main ideas presented in this article.

We should not analyse these works purely as a product of their context, nor in the belief that their context was determined by the author's ideas. Rather, we will seek to understand how his works acquired meaning by negotiating with context, i.e., how they were influenced by context, and to which extent they also contributed to shaping context. Moreover, we will approach context not as unique but as manifold, and replete with contradictions. Historically, people lived in many worlds at the same time, with many meanings and actions (Revel 2009: 134, 136).

\section{Brazil and the Asian-African World}

Menezes's first book, O Brasil e o Mundo Ásio-Africano (Brazil and the Asian-African World, 1956), is a defence of Western civilisation, but also a claim that Western countries were failing to convey their values. The main cause of the downfall of European imperialism, he argues, was the 'almost complete lack of idealism and spirituality in the relations towards races that [Europe] deems inferior' (Menezes 2012: 26). However, this is not the case with Portuguese colonialism. In fact, Portuguese colonies should be an example to the Belgians, French and British, because they depicted how the 'white man could live peacefully and with the real possibility of participating with the natives, as equals, in the new nations that arise in the black continent' (Menezes 2012: 77). These excerpts show the complexity and constriction of the context to which Menezes was situated. They highlight the deep ties between Brazil and Portugal, preventing even a bold intellectual like Menezes to take a bigger step in the defence of decolonisation.

The complexity of this context emerges again when the author pleads for Portuguese sovereignty over Daman, Diu and Goa, in India. According to Menezes (2012: 126127), those were not colonies, but legitimate Portuguese overseas provinces. However, a few pages later he regrets Salazar's unwillingness to resolve the issue with a plebiscite, and argues that Portuguese intransigence in India could lead Portugal to a disastrous struggle at the exact moment when anti-colonialism was on the rise:

In a war like this, China and Indonesia would certainly join forces with India and use the occasion to immediately, without further di- 
alogues and delays, seize what is still left to Portugal in the East. The good reputation of Portuguese colonialism itself, well-known for its antiracism, would suffer no smaller loss (Menezes 2012: 136).

Menezes was thus split between praising the Portuguese colonial heritage and enthusiasm for Asian liberation. In fact, Brazilian diplomacy in the 1950s often supported the idea that Portugal had overseas provinces, not colonies, where it led a Christianising mission. When Brazil tried to convince Salazar to relinquish colonialism, this attitude conflicted not only with the stance of the Portuguese regime but also with the opinion of many Brazilians who did not wish to see their country going against its former colonial master (Gonçalves 2007: 36).

If the establishment of relations with Africa was justified by historical transatlantic ties, the reasons for establishing relations with Asia were less clear. Menezes was aware of and decided to search historical elements that legitimised a rapprochement with the East. He called upon the historical ties between Portugal and Thailand (Siam) between the $16^{\text {th }}$ and $18^{\text {th }}$ centuries to justify a bigger presence of Brazil in the region. Thus, diplomacy turned into a path to rescuing memory:

Siamese nowadays, well-known for their outgoing, philosophical and Buddhist nature, know little about the traditions and the reputation of the Portuguese who were once here. Portugal is often remembered by modern inhabitants of the country solely as the owner of Macao, and for this city being the largest smuggling centre between China and Siam. However, encouraging a Portuguese 'presence' through conferences and history courses, the exchange of cultural delegations, together with the 'presence' of Brazil from the moment our country establishes diplomatic relations with Siam, could rekindle some of these past memories, this reputation of a country that could so easily conquer the long-lasting friendship of such an exotic, different and faraway people (Menezes 2012: 118).

More than setting an example for colonialist nations, he argues, Portugal was also the link in the chain uniting Brazil and Asia, since Brazil was the heir of Portuguese colonialism, and its rapprochement with Thailand an attempt to revive lost ties. Brazil should continue and improve the historical mission led by Portugal over the centuries: if Portugal took to Africa and Asia, the 'example of the white man, of the European who lacked bias, we [Brazilians] are able to display an individual whose ethnic and moral formation make him unable to have those [biased] feelings in sight' (Menezes 2012: 285-286).

Reinhart Koselleck observes that history is built upon the tensions between the space of experience and the horizon of expectations: past experiences and present perceptions justify the hope that something will happen in the future (Koselleck 2006: 306-318). Therefore, the space of experience in which Brazil/Portugal had friendly relations with the East justified a horizon of expectations where Brazilian diplomacy would break down distances and grow roots in the region. Far from being a radically new proposal, or lean- 
ing towards communism, the rapprochement with Asia and Africa meant the revival of significant historical values to Brazil.

Thanks to the 'psychological cocktail' of its people, Menezes wrote, the Philippines should play the role of building a bridge between East and West, though such role was threatened by their former colonisers:

The situation of the Philippines is indeed difficult. Eastern due to its origins, Latin in its largest centres due to Hispanic tradition and, nowadays, American due to the deep influence it suffered and keeps suffering. If, geographically and racially speaking, the Philippines are an extension of Malaysia, culturally and sociologically speaking its people are still deeply Spanish. However, the Americanisation is so intense (if the United States do everything they can to reproduce their way of being and living in countries faraway and out of their politic and economic authority, what to say of those who lie entirely within their orbit?), that the Eastern and Spanish characteristics are losing ground in some sense (Menezes 2012: 176).

Menezes regards the USA as one of the best examples of how the West is failing to share its most precious values, thanks to the strength of consumerism:

When the impact of the new way of eating, dressing, dancing, having fun and furnishing the house loses its charm and novelty; when he no longer drives the vague and weak human attention to the automatic bottle opener, the electric knife sharpener, the radio, the TV and even the nuclear reactor; when he starts considering the air-conditioner train, the jet plane and maybe even Ford and Chevrolet [...] as superfluous stuff, the Asian will start wondering to which extent the Western man provided him with significant and everlasting contributions (Menezes 2012: 191).

Once again, we notice the complexity of the Cold War years in the author's work. He gives new meaning to the idea of a West, separating it from the USA and tying it to Brazil, heir of the Portuguese Empire. Alongside with Spain, he regards Portugal as the only colonial power concerned with sharing not only material assets but also Christian values with the colonised people, thus emphasising its superiority (Menezes 2012: 24). He therefore writes: 'Especially in countries like Siam, who only now started having contact with our bourgeoisie and oil-minded civilization, the United States need to think less in terms of military and material aid and more in terms of spiritual understanding' (Menezes 2012: 192).

This idea of an alternative West, not to be confused with capitalism and the USA, clashed with the geopolitical views of General Golbery do Couto e Silva, one of the main Brazilian strategists at that time, who later influenced foreign policy during the first years of the military regime. According to Golbery, to belong to the West meant to belong to the 
North American sphere of influence, and any diversion from an alignment with Washington was regarded as a leaning towards communism (Gonçalves and Miyamoto 1993: 214). Therefore, according to Menezes, improved relations between the West and Asia-Africa relied on the spiritualisation of such relations and on subsequent Brazilian leadership. Furthermore, the future of the world did not revolve around Washington and Moscow, but around the emerging forces:

Therefore, to sum up, one could say the future of the world will not be decided by the Russian-American political game, nor by the military power of these two giants, but by the solution of the racial problem, or, even better, by the solution of the problem that results from different skin pigmentation. One can reach this conclusion through the following question: can these two superpowers coexist or fight without the help of the rest of the non-Western world? Obviously not (Menezes 2012: 281).

Moscow and Washington relied on the 'coloured people', which bestowed strength on the Third World. Here we can see the symptoms of a new stage in the Cold War emerging from Menezes's work. The rise of non-alignment 'provided a window through which "Third World" leaders could lean without falling: the idea was to compromise with neither side of the Cold War, though leaving a door open to the possibility of compromising in the future' (Gaddis 2006: 118). Therefore, while the Cold War acquired a global scope, its paradoxical effect was to empower people who recently had no power at all. It was the awakening of the autonomy: 'The tails started wagging the dogs' (Gaddis 2006: 123).

According to Menezes, Brazil's status as a multiracial country was a passport to this new world, and he argued that Brazilian policy towards the Afro-Asian world should follow two paths. On the one hand, it should be situated in the North American struggle against communism, though condemning it whenever it leads to racism or threatening the sovereignty of emerging countries. On the other, Brazil should entice 'African and Asian crowds using our main political-diplomatic weapon - the almost perfect racial and social equality that exists in Brazil' (Menezes 2012: 291-292). As we can see, Menezes was a follower of the anthropologist Gilberto Freyre, whom he calls 'a great master. Freyre's ideas gave birth to luso-tropicalism: the belief that the greatest legacy of Portuguese colonialism in Brazil was a melting pot that produced the country's racial tolerance. In fact, Freyre's ideas played a significant role in Brazilian IFP. He wanted to foster Brazilian diplomatic ties with Africa as long as they did not jeopardise relations with Portugal (Leite 2016: 266). Hence Menezes's more moderate view of Portuguese colonialism than those of other European powers, and his reluctance to support the Indian incorporation of Portuguese enclaves.

Appealing to history once again, Menezes goes back to Brazil's colonial past and its condition as a peripheral country, and finds an important link between it and Asia-Africa: the anti-imperialist struggle. It was necessary to 'gradually, inexorably, no matter whom this may hurt, insist that, despite being Westerners, [Brazilians and Europeans] are not "brothers under the skin." Brazilians are 'as anti-colonialists as any other country in Band- 
ung, for although Portuguese colonialism in Brazil was among the mildest and most patriarchal in its social aspects, politically and economically speaking it was one of the most violent and oppressive ones' (Menezes 2012: 292). Moving on with this idea, he states:

We had a Tiradentes, we had exiled people, we also had our martyrs, our victims, our patriots just like any other colony in Asia and Africa. Besides being Portugal's colony, we were also victims of the greed of the French and Dutch who seized power and held sway over large portions of our territory. We are - and we have proved it - truly and completely anti-imperialistic. We had the Eastern Province [i.e. Uruguay] in our hands and we bowed down before its inhabitants' claims; we won bloody and long-lasting wars and respected the integrity of Paraguay; with large borders and substantial number of neighbours, we managed to settle them in an environment of peace and mutual respect under the magical authority of Rio Branco (Menezes 2012: 292).

The author concludes this idyllic rendition of Brazilian history as follows: 'These facts of our History are completely unknown in those regions, and its dissemination would carry a great psychological value' (Menezes 2012: 292). Therefore, spreading Brazilian history in Asia and Africa would be a powerful tool for evoking the sympathy of those people, because through history it was possible to prove that Brazilians, Africans and Asians had the same past and the same aspirations.

These excerpts mitigate the author's initial praise of Portuguese colonialism, since they highlight a narrative of colonisation that seeks to place Brazil and its Afro-Asian 'brothers' on the same level. Menezes thus faced the dilemma of praising Portuguese heritage on the one hand, and seeking to bring Brazil closer to the Third World on the other. This conflict pervades his books. One must face these contradictions as an expression of narrativity. Jörn Rüsen (1966: 89-90) states that one of the contributions that narrativity brings to historical knowledge is retrospectivity, i.e., the idea that the way in which one approaches the past is influenced by one's future aspirations. Menezes's aspirations were related to Brazil's role in 'spiritualising' international relations.

Another consequence of narrativity is what Rüsen calls perspectivity: the way in which one reads the past is deeply connected to the present one lives, i.e., the political problems one faces. In the case of Menezes, this was the apathy of Brazilian diplomacy towards underdeveloped countries, and the Europeanised mentality of Brazilian political and intellectual elites.

Finally, selectivity is a consequence of narrativity which shows us that only certain kinds of information extracted from the sources are relevant for research, i.e., those who meet the needs of the production of meanings. Considering that Menezes wanted to imbue Brazilian foreign policy with new meaning by including Afro-Asian countries among its concerns, it is understandable that he only included historical information that justified such claims. 
When we analyse these ideas in the light of the negotiation between text and context, we become aware of the complexity of the world Menezes was living in, but also manage to understand this complexity. Latin America's position in the face of Third World solidarity was dubious. The dependency theory ${ }^{2}$ placed Asian, African and Latin American countries on the same level on the grounds that they were all subject to the same structural conditions as peripheral countries (Leite 2011: 37). However, the relations between Latin American countries and their former Iberian colonisers were quite different from those of Asian and African countries. By that time, emancipation was a contemporary issue in Asia and Africa, whereas Latin America had already broken its colonial chains more than a century ago.

Moreover, imperialism took a different form in Latin America than in the East. As Prado Jr has argued, in the latter, 'the contradictions raised by the process of imperialist penetration soon arise in deep conflict against the economic interests and social and political forces,' whereas in Brazil 'the European, and soon also the North-American imperialists faced [...] a civilization and a culture that was essentially similar to theirs because they shared the same roots' (Prado Jr. 1966: 145, 183). Once they had achieved their independence, the language, culture, institutions and (in the Brazilian case) even the rulers of the new Latin American countries remained the same as those of their former colonisers.

When Menezes associates the Brazilian anti-imperialist struggle with the Asian-African one, he overlooks this significant historical particularity. However, as noted previously, this particular way of interpreting events does not mean that the author fraudulently distorted events. It is only a sign of the inevitable partiality that pervades the production of historical knowledge: 'as historical subjects, we cannot avoid being partial. As strong as the positivist fantasies may be, they impoverish the writing of History. The accuracy may sometimes mean shallowness' (Lima 2006: 95). If Menezes were more worried about accuracy than about his political beliefs, his writings would certainly not spark our interest in the way they do now.

To make Brazil known in Asia and Africa meant having an autonomous policy, without submitting to the superpowers. In 1954, for example, Brazil voted against an Indonesian proposal in respect of New Guinea, a region disputed by Indonesians and the British. However, this vote received almost no exposure in the Brazilian press:

How many of our 55 million Brazilians possibly know what is and where is Indonesia? How about New Guinea? Obviously, these are the kind of news the readers interested in politics usually overlook with the same lack of interest the diligent readers of the football pages despise the scores of the second league matches. However, what a great loss this meaningless event represents for our South East Asia policy (if one day, as one may expect, we manage to have our own policy in this region). What a useless animosity it may raise. What a great mistrust this attitude of such an unknown country for the Asians, as some Asian countries are unknown for us, may have aroused (Menezes 2012: 297). 
Menezes's effort to encourage a rapprochement between Brazil and the Third World was an attempt to convince Brazilian diplomacy and public opinion, which at that time faced the awakening of the Afro-Asian world with a mix of fear and disdain. As we have seen, Golbery do Couto e Silva rejected any path other than alignment with Washington. Moreover, the Brazilian view of the Afro-Asian solidarity was 'pervaded by the ideological biases spread at that time across the "Western" world, to which Brazil uncritically believed it belonged' (Souza 2011: 198). Brazil faced the Bandung Conference with scepticism. Its press and diplomacy usually regarded Bandung as 'the others', the 'Easterners' or the 'non-Christians.' When they were not identified as communists, they were 'dangerously close to them, whereas North-American and Portuguese interests were regarded as Brazilian interests (Souza 2011: 198).

Fostering ties between Brazil and the East should also imply improved cultural diplomacy. Among the strategies proposed by the author was the exhibition of Brazilian films, especially the ones about Portuguese colonisation, in order to depict its lack of racism. Friendly football matches in the region would play an important role in 'showing Asia, better than by any other means, our perfect racial equality', depicting how black football players managed to earn a lot of money (Menezes 2012: 326-328). Once again, we notice the author's acceptance of the 'racial democracy' thesis, as stated by Gilberto Freyre. Brazilian music would also be a relevant strategy for fostering Brazilian culture:

I will never forget the day I heard, in a kampong [village] from Yogyakarta, right in the heart of Central Java and in one of the most exotic places that can still be found in this world shrunk by the airplane, a boy in his sarong whistling 'Chiquita Bacana'3 (Menezes 2012: 328).

He also believed the similarity of climates in Brazil and South East Asia could encourage exchanges in the field of architecture:

There are towns in South East Asia with a climate quite similar to Brazilian towns at the same latitudes. Singapore and Jakarta have almost the same climate as Belém or São Luís, in Maranhão. The former has officially showed interest in getting to know our architecture. The latter, which may be considered a town just because of the anthill living there, since architecturally it is still a Dutch colonial village, could be a window in Asia for Brazilian building styles (Menezes 2012: 329-330).

Therefore, culture is no stranger to the history of international relations. Far from being just an epiphenomenon of politics or economics, culture may be regarded as an element 'which, to a lesser or greater extent, guides the foreign policies of countries and which, thus, is used by the State in search for influence and status in the international scenario' (Lessa and Suppo 2007: 223-224). 


\section{Asia, Africa and Brazilian Independent Policy}

In Ásia, África e a Política Independente do Brasil (Asia, Africa and Brazilian Independent Policy, 1961), Menezes continued his efforts to associate Brazil with underdeveloped countries, thus going against public opinion that favoured an alignment with the USA. He stated that the North-South cleavage was more important than the East-West one, thus expressing the multifaceted context in which he was writing:

If there is a bloc we may belong to within certain limits, it is that of underdeveloped countries; that which stretches across the Southern latitudes of Earth, in that unaided, oppressed and overpopulated area. West? What is that West to which these 'ultra-indigenous', disguised as champions of democracy, want to give us the illusion of belonging? Certainly that of the white, rich, technically advanced countries that despise coloured people (Menezes 1961: 9).

Therefore, Menezes had a remarkable ability to perceive the changes the world was going through - changes that were largely ignored by the Brazilian political and intellectual elites.

He proposes a new cleavage according to which the contrast between centre and periphery turns out to be more relevant than the one between Washington and Moscow. By doing so, his texts contribute, as Revel would put it, to the configuration of their context. To Menezes, the struggle between communists and capitalists made no sense in the eyes of the Third World:

The cliché that there is a struggle between those who defend a free world and human rights against a materialist enemy who oppresses freedom does not make sense to Eastern, black or Arab ears. Were not those same Westerners who oppressed them and want to keep oppressing them, if not politically, at least economically? [...] Actually, what most Asians and Africans want is to search a path that delivers them from their former oppressors and from an eventual Soviet yoke. That search had remarkable outcomes. After few years of independence, Asians and Africans have been practicing a diplomacy as worthy as the traditional countries (Menezes 1961: 61).

While in the 1950s the author had a moderate view of Portuguese colonialism, in 1961 his hesitation vanished. This new attitude may be a consequence of 1960, a year known as the 'year of Africa' due to the 17 countries that achieved their independence, paving the way for other emancipations. At this point, Menezes firmly sided with the colonised, even against the more 'human' colonial powers (i.e., Portugal and Spain):

Let's be honest: how can the native believe the advice of the West when, nowadays, even those colonial powers that are more human when dealing with racial issues, like Portugal and Spain, stick to a 
conservative position; when the leader of democracy [the United States] does not have the courage to show its support to the African in his struggle? (Menezes 1961: 40).

In this power vacuum, he argues, Brazil should play a leading role in the rise of the Afro-Asian world. Interestingly, however, while propagating Brazilian leadership of the underdeveloped nations, he ends up encouraging rivalries among those same nations: 'Well, let's think, who, outside this area, is better than Brazil in fostering and supporting ideas of a moralisation of international relations between the people?' (Menezes 1961: 70). Why Brazil? Because 'We were already a colony, we were never imperialists and, above all, who is better than us, who do not carry any past or present guilt, in unfurling the flag of a crusade in favour of the weak?' (Menezes 1961: 70). Finally, the author states: 'Are we going to keep letting far less prepared countries like India, Egypt, Mexico, Venezuela and now Cuba steal this honourable task from us?' (Menezes 1961: 70-71).

He even speaks of a 'manifest Brazilian destiny': to spread the ecumenical Christian message in Asia. This was the West Brazil belonged to, according to the author: Christian, Iberian and conservative, nothing like the materialist and belligerent West represented by the USA:

It is up to this racial melting pot, from where the $21^{\text {st }}$ century cosmic $\operatorname{man}^{4}$ will certainly arise, the task of doing something for Christianity in regions like China, where the mentors of our religion are, unfortunately, forced to embrace attitudes way too silent and of fruitless long-distance opposition (Menezes 1961: 132).

Belonging to the Christian West did not prevent Menezes from grieving over the fact that Brazilian elites were too Europeanised, either due to tradition or to sheer snobbery. In his view, these elites were confusing their white skins and the conservatism of their ideas with those of the majority of the country's population, which were not a part of so-called Western civilization (Menezes 1961: 72).

\section{Underdevelopment and International Politics}

In 1963, Menezes published Subdesenvolvimento e Política Internacional (Underdevelopment and International Politics), in which he expressed his repudiation of the arms race between the Soviets and North Americans. The notion of 'national security', he argued, was turning into a 'Machiavellian Satan' that legitimised the sacrifice of each and every human being - either in the 'NKVD torture dungeons and in blood orgies in the streets of Budapest,' or in the shape of 'an astute devil who, if does not destroy the spirit, bursts it, galvanises courage and crushes reputation' (Menezes 1963: 16).

This book appeared one year after the Cuban missile crisis, during which an astonished world witnessed the escalation of tensions that almost led to a nuclear war. After the crisis, both superpowers realised that stable relations were more important than honesty or justice. Any alternative to this stability was too frightening to contemplate. In other 
words, it was more important to save the world from nuclear destruction than to assure moral values (Gaddis 2006: 173).

Menezes was aware of this new reality. According to him, the solution for the tensions between Washington and Moscow lay in the encouragement of contacts between these countries. The more isolated the US and Soviet blocs remained, the more this would jeopardise their coexistence. Therefore, Menezes argued that encouraging the visits of citizens from non-communist countries to the Eastern Bloc and vice versa was a powerful weapon for weakening communist dictatorships from the inside. The West should not reject such contacts, considering the superiority of its principles:

If the United States have, indeed, faith in the values of their civilization, they should not fear these contacts. The strong and healthy body does not fear the infection of microbes. The perfect and sane brain is not afraid of any indoctrination carried out by communists, even the more fanatic ones (Menezes 1963: 30).

Just as important as avoiding a tragedy emanating from superpower rivalry was the strengthening of the 'non-committed' countries, i.e., the non-aligned.' Menezes believed that 'the larger and more united the neutralist bloc, the bigger the possibilities of defence for the rest of the non-Russian and non-American mankind' (Menezes 1963: 31). Latin America was a privileged area for a dynamic neutrality, since its people were increasingly attuned to the ideas of an independent foreign policy and of support to other underdeveloped countries in Africa and Asia.' In that scenario, nothing could avoid the 'effective, natural and fair leadership of Brazil' (Menezes 1963: 45).

This book thus strengthens the notion that Menezes's main goal was to encourage Brazilian and Latin American politicians, diplomats and intellectuals to side with Asia and Africa. Afro-Asian solidarity should reach the Western hemisphere and encompass Latin America, which so far had an ambiguous position on the matter. In fact, Latin America played a minor role at the first non-aligned summits. Only three Latin American observers (from Bolivia, Brazil and Ecuador) attended the Belgrade summit in 1961. This increased to seven in Cairo (1964 - Argentina, Bolivia, Brazil, Chile, Mexico, Uruguay and Venezuela), but dropped to six in Lusaka (1970 - Bolivia, Brazil, Chile, Peru, Uruguay and Venezuela).

The rapprochement towards Asia and Africa was not only morally but also politically and economically legitimate. Previously, Menezes's arguments were directed at the Brazilian authorities, whereas in this book they were directed at Latin America as a whole:

The fears and luke-warmness of most of the Latin American countries make us believe they still haven't understood that it is far more useful in terms of the 'real politics' to support the Afro-Asian bloc in its struggles for political and economic independence (which, in a certain way, will be shared by them, since they are also underdeveloped), than to support Europe, which is about to lose, quickly or 
gradually, its foundations as economic superpower, even beyond its borders (Menezes 1963: 37).

A good example of this ambiguity is the Brazilian decision to abstain from voting on Angolan and Algerian independence in the 1960s, and its vote against the rights of communist China to gain a seat in the UN General Assembly (Rodrigues 1966: 155; Bueno and Cervo 2015: 343).

Menezes's plea for close South-South cooperation does not prevent him from anticipating tensions within that same South. At that time, African countries were supplying more and more goods previously monopolised by Latin America to Europeans and North Americans at competitive prices, thus thwarting Menezes's expectations of unity. According to him, it was important to foster the union of these countries in order to demand fair prices from the First World (Menezes 1963: 127).

Other tensions foreseen by the author were those between Afro-Asian nationalists and Afro-Asian Americanists. The latter were African and Asian countries that 'due to the financial interests of their governments or their own leaders, remain tied to the hesitating anti-colonial policy of the United States' (Menezes 1963: 128). Noting that in the 1959 UN vote on Algerian independence, Turkey, Thailand and Iran sided with France, he asserts: 'This decision, immoral and opposed to countries that are brothers in race and continent, will certainly lead to upcoming retaliations' (Menezes 1963: 129).

In fact, there were even clashes at the Bandung Conference that almost brought the event to a premature end. Many of these were between non-aligned countries and pro-Western, anti-communist, anti-neutralist countries, i.e., the majority of the participants (Mackie 2005: 16). Therefore, the South-South agenda was a social construct deeply influenced by the Cold War ideological disputes.

Underdevelopment and International Politics was published a year before the advent of Brazil's military regime. In one of few passages where the author mentions military regimes in Latin America, he states that these dictatorships 'harm the well-being of people' and result from the economic free-riding that had seized the continent (Menezes 1963: 129-130). It appears that the author was not molested by the new regime, and might even have benefited from it. Like the first edition of Brazil and the Asian-African World, Underdevelopment and International Politics was published by the publishing house GRD. These were the initials of its founder, Gumercindo Rocha Dorea, who also wrote for A Marcha, a newspaper for the Partido de Representação Popular (PRP).

The PRP was a post-war political party that gathered former integralists, i.e., members of the Brazilian fascist-inspired integralismo movement that was active during the 1930s. Gumercindo was also a close friend of Plínio Salgado, leader of the PRP, founder of the integralist movement, and a supporter of the military coup. In that same year of 1963, GRD published a novel by Rubem Fonseca sponsored by the Institute of Economic Research (Instituto de Pesquisas Econômicas, IPES), an institute led by General Golbery do Couto e Silva and a supporter of the military coup. After the coup, GRD published many books in favour of the military regime (Enciclopédia Itaú Cultural 2018). 
In October 1965, Menezes was appointed as ambassador to Pakistan (Federal Senate 1965). Given the status of this position, this posting suggests that he enjoyed good relations with the new regime. However, as we will discuss later, the Brazilian Ministry for Foreign Affairs managed to retain a degree of independence from the pressures of the military, and Menezes's posting does not necessarily imply a connection with the military regime. Even if it did, Brazilian diplomats certainly did not enjoy postings to Pakistan, given its distance and the fact that it was an underdeveloped country. As we shall see, in 1954 Menezes refused to serve in Pakistan. In March 1969, during a period as head of the Department for Commercial Support, he was due to lead a mission of Brazilian traders and industrialists to the Persian Gulf. However, according to the newspaper Correio da Manhã, the mission was cancelled (Antônio 1969: 1-2).

In one of the most intriguing passages in Underdevelopment and International Politics, Menezes expresses his fears that the superpowers might use the same predatory strategies in outer space as those used on Earth, in such a way that 'when we land on a planet of our solar system, the inhabitants of these planets will be immediately reputed "lackeys of capitalism" or "fellow travellers" (Menezes 1963: 148-149). To avoid this deplorable situation, the author advocates the internationalisation of the stars:

In 1959, at the Escola Superior de Guerra ${ }^{5}$, we suggested that Brazil should propose a resolution based on that idea. Actually, due to its anti-racist and anticolonial traditions, no country is in a better position than ours to defend such a proposal. Unfortunately, India played the major role. In 1961, the head of the Indian mission presented a proposal almost similar to the one we supported (Menezes 1963: 139).

The themes in this book can be synthesised in terms of what the author himself calls the 'theory of resentment, i.e., a loosening of the restrictive binary of socialism and capitalism. According to him, countries should be in a position to make free choices falling in neither of those two camps:

Marx wrote only about the changes from capitalism to socialism. We, on the other hand, plead for the establishment of a universal consciousness that allows not only such transactions, but also opposite transactions, i.e.: the return to aspects of democratic capitalism in countries that were forcibly socialised, without that implying the terrible revolutionary crises advocated by the German theorist (Menezes 1963: 143).

He also argues that intellectuals have a major role to play in creating this benign and enabling international relations environment, and calls upon them to contribute, in their various disciplines, to the moralisation of international relations. Philosophers should 'emphasize the relations between International Politics, Ethics and Morality'. Historians should teach history 'under a universalist rather than a national approach.' Finally, 
'the ideas, the contemporary scientific theories in the field of Mathematics, Physics, Psychology and Biology, should be mainly applied in the task of improving interstate relations' (Menezes 1963: 150).

Therefore, the scientist, just like any person of letters, 'must be deeply aware of his eventual complicity in the disintegration of international relations, or his role in improving it' (Menezes 1963: 150). Just as it is 'very important for every philosopher to be something of an internationalist, it is also vital for mankind that every internationalist must be something of a philosopher' (Menezes 1963: 182).

\section{A Diplomat in the East}

In 1997, Menezes published a small book divided into two parts. In the first part, entitled Um Diplomata no Oriente (A Diplomat in the East), the author recalls his experiences as a diplomat in Indonesia during the 1950s. He started writing this in 1956, but only finished it in the 1990s.

It emerges that Menezes served in Indonesia against his will. As a diplomat at the start of his career, the doors of the most attractive diplomatic posts like Rome or Madrid were shut to him. He was presented with three options. He refused Karachi (Pakistan) for 'disliking the Arab habit of segregating the beautiful sex', besides finding Karachi 'a city with almost no trees, no vegetation' (Menezes 1997: 3). He also refused Taipei (Taiwan) because 'Taiwan was not China, it was a fictive country' (Menezes 1997: 3). This left only Jakarta: 'I don't really know what made me choose Indonesia. Perhaps the fact that it was an exotic country, just recently open to Western snooping, considering Netherlands had kept it as an isolated region' (Menezes 1997: 3).

The author and his family left for Indonesia in January 1954. That same year, in September, the first Brazilian ambassador to Indonesia - Federal Deputy Oswaldo Trigueiro de Albuquerque Melo, from the right-wing União Democrática Nacional (UDN) - arrived in Jakarta. Trigueiro was a firm anti-communist and anti-neutralist. In 1955 he criticised the visit of the Indian prime minister Jawaharlal Nehru to the Soviet Union, accusing the Soviets of seeking to seduce the Third World and the Indian leader of dishonesty for playing with both sides of the Cold War. Trigueiro also criticised Indonesian rapprochement towards the communist bloc, thus reproducing a recurrent idea among Brazilian diplomacy that regarded Third World neutralism as communism in disguise. Trigueiro stated that Bandung had vague and unclear objectives, and regarded it as a threat to Western values (Souza 2011: 126-128, 200-201).

As we can see, Menezes despised everything Trigueiro stood for, but admired him nonetheless, praising his ability to impress local authorities. He enthusiastically describes the ceremony at which Trigueiro presented his diplomatic credentials in the following terms: 'President [...] Sukarno was lovely on the evening when Ambassador Trigueiro delivered his credentials' (Menezes 1997: 38). In his speech, Sukarno 'showed he was quite familiar with many issues from our country, and even lectured about Brazilian contemporary painting' (Menezes 1997: 38). Soon afterwards, he was fascinated by watching a 
'growing bond' between the two countries: 'It was the first official bond in time and space between the two great and upcoming countries: Brazil and Indonesia. It was the first business card Brazil delivered in South East Asia, a key region for the world within a short time' (Menezes 1997: 38).

Political events in Brazil would soon affect Trigueiro's position. Thus Menezes writes that 'in the gap between Getúlio Vargas's death and Juscelino's inauguration, I don't know what "genius" in Itamaraty or Catete ${ }^{6}$ suggested that all ambassadors designated by former heads of state should be dismissed' (Menezes 1997: 49). Trigueiro was one of them. Brazilian ambassadors 'considered it a demerit to serve in newly independent countries in Asia and Africa, and Menezes himself was relieved to find he was being transferred to Europe, since he had lived for 'more than two years in a place with harsh climate and life - my family did not know Europe, and I had not been there for more than 20 years' (Menezes 1997: 49).

Trigueiro's farewell dinner, held by the Indonesian government, was 'the first dinner offered to a Western country representative', thus consisting a 'break with nationalist, Afro-Asian and Indonesian rules' (Menezes 1997: 36). His commitment to Brazilian engagement with the Third World helps to explain his emphasis on the ambassador's ability to captivate local authorities in the midst of Sukarno's anti-imperialist euphoria.

Menezes was such a passionate anti-imperialist that his engagement went beyond bureaucratic levels and pervaded his private life. Thus he describes a mishap in which he accidentally ran over a young Indonesian student in a crowded street. An enraged crowd gathered around the car and shouted that the driver was from the Netherlands, Indonesia's former coloniser. Filled with courage, Menezes climbed on the car and yelled that he was a Brazilian. Fortunately, a friend of the injured student 'knew how to distinguish a coloniser from a man who came from an underdeveloped country like ours' (Menezes 1997: 52). The young man thus urged the crowd to 'notice I was a visitor, a guest from a country on the other side of the world that had also been an exploited colony, just like theirs' (Menezes 1997: 53). The crowd understood the message, and gradually broke up. Menezes then drove the two friends to hospital where the injured man soon recovered.

\section{The legacy of Bezerra de Menezes}

Despite the hostility of much of Brazilian diplomacy and public opinion towards the Afro-Asian movement, there were also diplomats who argued that Brazil should play a more prominent role in the Third World. By the end of the 1950s, diplomats such as Sérgio Corrêa do Lago, Jorge Paes de Carvalho and José Cochrane de Alencar believed Brazil should be more assertive in the debates about decolonisation, and take account of the aspirations of Afro-Asian people. They believed such a change of attitude would benefit Brazil's projection in a changing international scene (Penna Filho e Lessa and Mapa 2016: 14-15).

In the 1960s, the distinguished historian José Honório Rodrigues turned to the ideas of Gilberto Freyre to point out that before the arrival of the Portuguese Royal Family in Brazil in 1808, Asian traces could be seen in its landscape, clothing and habits. Once the 
Royal Family had visited Brazil, 'Eastern Brazil' was erased, and the country gradually acquired European trappings. Just like Menezes, Rodrigues interprets independent foreign policy not as a leaning towards communism, but as a restoration of two values that played significant role in the Brazilian monarchy in the $19^{\text {th }}$ century: the rejection of entangling alliances that subordinated Brazil to superpowers (adopted by Emperor D. Pedro II since 1844), and the opening of Brazilian ports to other nations (Rodrigues 1966: 112-113, 134).

Also like Menezes, Rodrigues believed that an alliance with the West did not mean an automatic alignment with Washington. Instead, he asserted, 'we are a mixed people with many ethnicities and cultures, and it would be a mistake to whitewash and disguise as Western our ambivalences and acculturations' (Rodrigues 1966: 196). He also did not believe that the East-West cleavage was the most significant, since 'nowadays we would rather talk about a North-South cleavage, or developed and developing nations' (Rodrigues 1966: 196).

The importance of Menezes's texts in the configuration of Brazilian context becomes clear when we realise that Brazilian diplomacy was increasingly attuned to his ideas. Despite President Juscelino Kubitschek's caution in supporting decolonisation, between 1958 and 1960 Brazil opened diplomatic missions in Ceylon, South Korea, Thailand, Malaysia, the Philippines, Southern Vietnam, Ghana, and the colonies of Angola and Mozambique (Vizentini 1995: 162).

The turning point for Brazilian diplomacy was the independent foreign policy of presidents Jânio Quadros and João Goulart (1961-1964). In 1961, Jânio Quadros founded the Brazilian Institute for Afro-Asian Studies in order to enhance cooperation with the newly independent countries through scholarships, lectures and academic exchange programmes. In a speech in the National Congress, Jânio condemned all forms of colonialism, and declared Brazil's support for decolonisation. In April 1961, Brazil established embassies in Senegal, Guinea, Nigeria, Ivory Coast and Ethiopia, as well as consulates in Kenya, Rhodesia (now Zimbabwe) and Congo-Leopoldville (now the Democratic Republic of Congo). Brazil also paid growing attention to Asian countries (especially China and Indonesia) due to their status as potential trade partners. In 1961, President Sukarno visited Jânio, and vice-president João Goulart visited China (Vizentini 1995: 223, 225; Leite 2011: 99, 105-107).

Not surprisingly, Menezes praised Jânio Quadros for extracting Brazilian diplomacy from the 'contemplative-decorative phase in which it had vegetated for a long time' (Menezes 1961: 70).

Even the 1964 military coup did not constitute a break with the Third World. Although President Humberto de Alencar Castelo Branco was strongly influenced by the ideas of the Escola Superior de Guerra, which advocated unconditional alignment with the West, 'the ideas originating from an independent foreign policy and rooted in the Ministry of Foreign Affairs continued to influence the foreign policy of the first military regime' (Alves and Viana 2014: 693). Moreover, the military regime did not retreat from relations with the Third World, and in some cases even strengthened them. Thus Castelo Branco signed 24 agreements with Third World countries, comprising 46\% of the inter- 
national agreements signed by Brazil. By contrast, international agreements signed by the Quadros and Goulart governments comprised only 25\% of the total (Alves and Viana 2014: 696).

Therefore, Castelo Branco's foreign policy was not a 'step out of the cadence, as some authors would put it (Bueno and Cervo 2015: 393), since it upheld several strands of the independent foreign policy. From 1964 onwards, Brazil played an important role in the United Nations Conference for Trade and Development (UNCTAD), emerging 'both as a regional leader and a leader of the entire intellectual heritage of Third World countries' (Kocher 2015: 14). If neutralism and anti-imperialism did not succeed in driving Brazilian government's attention to the Third World, economic development did. The issue of economic development thus played a major role in attuning Brazil to the 'Bandung spirit' (Kocher 2015: 10).

Ten years after Menezes served in Indonesia, Raul José de Sá Barbosa, a Brazilian diplomat in Jakarta, tried to implement some of his ideas, especially in terms of cultural diplomacy. When Sukarno forbade the exhibition of North-American films, in order to benefit domestic films, Raul Barbosa wrote: 'With the boycott of foreign films by the local film industry, the interest in films of the embassies has risen. Brazil, as a NEFO (New Emerging Force) country now has a great opportunity to make films' (Barbosa 1965). In a telegram sent in 1968, he asked Bossa Nova records to spread Brazilian music in Indonesia. He managed to arouse interest in Brazilian songs among 'small popular music groups, both in Jakarta and in the countryside,' besides promising to arrange modern instruments for the Sitompul sisters (a musical group from Jakarta) and for Surabaya orchestra (Barbosa 1968).

The 'responsible pragmatism' of President Ernesto Geisel in the second half of the 1970s was also an important moment in the history of Brazil's South-South agenda, as it recognised the independence of Portuguese colonies in Africa (Leite 2011: 142-144, 147). Brazil then saw the opportunity, 'as the major Portuguese speaking country, to become the most qualified advocate of the aspirations of these people to achieve development and autonomy' (Gonçalves and Miyamoto 1993: 232). The Brazilian National Security Council, which played a significant role in the foreign policy of the first military governments gradually yielded power to Itamaraty. The weakening of the National Security Council also paved the way for relations with communist China in 1974 (Gonçalves and Miyamoto 1993: 231).

However, external variables also played a role in that rapprochement. The further away 'external issues were from the national territory, like Angola and the recognition of communist China, the least was the influence of the military establishment on the Brazilian positions' (Amorim and Feldman 2011: 281-282). Therefore, geographical distance, which initially inhibited Brazilian rapprochement towards Asia and Africa, later encouraged it. International structures must be seen neither as sole inhibitors of the human actions nor as immutable phenomena, since they may not only obstruct human actions, but also support them (Tomich 2011). 


\section{Conclusion}

Jörn Rüsen (1996: 86-87) interprets historical cognition as a twofold activity. On the one hand, History has an objectivity related to information about the past, ensured by the historian's critical analysis. On the other hand, History also has a subjective face related to issues of practical life, as historical knowledge guides continued struggles for identity. This subjectivity is ensured by the political engagement of the historian. Objectivity and subjectivity, Rüsen asserts, are mediated by historical interpretation, which ensures objectivity by integrating empirical evidence about the past into the historical narrative, but also inserts subjectivity by relating this evidence to the political and cultural problems of the present.

In line with this perspective, Bezerra de Menezes skilfully used his interpretation of the history of Brazilian foreign policy (pointing out how close it once was to Asia and Africa, and how autonomous it was) to advocate a policy of resumed engagement with Asian and African countries. Diplomatic activity was linked to intellectual activity, thus showing how 'a life dedicated to rigorously understanding the world implies the ability to change it,' and highlighting the 'absolute complementarity between the active life and the contemplative life' (Rosanvallon 2010: 11).

Menezes believed that Brazilian foreign policy should look towards Asia and Afri$\mathrm{ca}$, and that dynamic neutralism, non-alignment, anti-imperialism and economic development should help Latin Americans, Asians and Africans to break with the bipolar world order. However, as we have seen, only economic development eventually played a major role in Brazilian rapprochement with the global South.

Dale Tomich (2011) believes structures provide small-scale actions not only with limits, but also with possibilities. When the idea of a Brazilian diplomacy focused on Asia and Africa was met with scepticism, Menezes already stated the opposite. Years before the Brazilian government and Brazilian citizens realised the importance of the Third World, Menezes saw that these geographically and culturally distant people were closer to them than they could imagine.

Within a few years, circumstances changed, and the rapprochement towards the Third World was increasingly appreciated not only by progressive thinkers. The texts of Bezerra de Menezes were one of the variables that helped to change this environment. Counterposing his ideas with the reality of the Cold War provides a good example of the negotiation between text and context. Or, as Dale Tomich puts it, it shows how important it is to flip the 'hourglass of History' in two ways: from structures to events, and back to structures.

\section{Notes}

1 Bezerra de Menezes lived between 1910 and 2006. He graduated in Social and Legal Sciences and worked as a surveyor, diplomat and head of the Department for Commercial Support of Itamaraty, besides being a member of the European Society of Culture and vice-president of the Brazilian Centre for Strategic Studies (Associação Nacional de Escritores 2018). He was the grandson of Adolfo Bezerra de Menezes, a doctor from Ceará who played an important role in disseminating Spiritism in Brazil (Gama 1966). 
2 This theory asserts that central states become richer at the expense of peripheral ones.

3 'Chiquita Bacana' is an old Brazilian carnival song.

4 'Cosmic race' was an expression used by the Mexican sociologist José Vasconcelos to refer to a new and better mankind that should arise from racial amalgamation (see Vasconcelos 1948).

5 The Escola Superior de Guerra is a Brazilian military academy.

6 Itamaraty is the Brazilian Ministry of Foreign Affairs, so named after the Itamaraty Palace in Rio de Janeiro in which it was previously seated. Catete was the seat of Brazilian government until 1960.

\section{References}

Alves, V C and S Viana. 2014. 'Ideias e Política Externa: As Relações do Brasil com o Terceiro Mundo durante o Governo Castelo Branco.' Contexto Internacional 36 (5): 683-708.

Amorim, C and L Feldman. 2011. 'A política externa do governo Lula em perspectiva histórica.' In F C de San Tiago Dantas (ed), Política externa independente. Brasília: FUNAG, pp. 275-301.

Antônio, M. 1969. 'Correio Diplomático'. Correio da Manhã. 22 January.

Barbosa, R J de Sá. 1965. Received letters - Jakarta - n. 109. Archives of the Brazilian Ministry of Foreign Affairs.

1968. Received telegrams - Jakarta - n. 4. Archives of the Brazilian Ministry of Foreign Affairs.

Bueno, Clodoaldo and Amado Luiz Cervo. 2015. História da política exterior do Brasil. Brasília: Editora UnB.

Dantas, S T. 1962. Política externa independente. Rio de Janeiro: Civilização Brasileira.

Enciclopédia Itaú Cultural de Arte e Cultura Brasileiras [online]. 2018. 'Gumercindo Rocha Dorea.' At http://enciclopedia.itaucultural.org.br/pessoa502009/gumercindo-rocha-dorea [Accessed on 5 June 2018].

Federal Senate. 1965. Speech $n$ 442. At https://www25.senado.leg.br/web/atividade/materias/-/materia/107405?o=c [Accessed on 5 June 2018].

Gaddis, J L. 2006. História da Guerra Fria. Rio de Janeiro: Nova Fronteira.

Gama, R. 1966. Lindos Casos de Bezerra de Menezes. São Paulo: LAKE.

Garcia, E V. 1997. 'O pensamento dos militares em política internacional, 1961-1989.' Revista Brasileira de Política Internacional 40 (1): 18-40.

Gehre, T. 2008. 'A política externa brasileira durante os governos militares: ideias, práticas e imagens (1964-1984).' Textos e Debates 2: 112-125.

Gonçalves, W da Silva and S Miyamoto. 1993. 'Os militares na Política Externa Brasileira, 19641984.' Estudos Históricos 6 (12): 211-246.

Gonçalves, W da Silva. 2007. 'História das Relações Internacionais.' In W da Silva Gonçalves e M L Lessa (eds), História das Relações Internacionais: teoria e processos. Rio de Janeiro: EDUERJ.

Kocher, B. 2015. 'Ecos desenvolvimentistas da Conferência de Bandung na política externa Brasileira.' Paper delivered at the $5^{\text {th }}$ Conference of the Brazilian International Relations Association (ABRI). Belo Horizonte, Brazil, 29-31 July. 
Koselleck, R. 2006. Futuro passado: contribuição à semântica dos tempos históricos. Rio de Janeiro: Contraponto and PUC-Rio.

Leite, F S. 2016. 'A Política Externa Independente em revista: de como ocorre a impressão definitiva da dimensão africana na política externa brasileira.' Temporalidades 8: 255-269.

Leite, P S. 2011. O Brasil e a cooperação sul-sul em três momentos de política externa: os governos Jânio Quadros/João Goulart, Ernesto Geisel e Luiz Inácio Lula da Silva. Brasília: FUNAG.

Lessa, M L and H R Suppo. 2007. 'O estudo da dimensão cultural nas Relações Internacionais: contribuições teóricas e metodológicas.' In: Gonçalves, Williams da Silva e Mônica Leite Lessa (eds), História das Relações Internacionais: teoria e processos. Rio de Janeiro: EDUERJ, pp. 223-250.

Lima, L C. 2006. História. Ficção. Literatura. São Paulo: Companhia das Letras.

Mackie, J. 2005. Bandung 1955: Non-alignment and Afro-Asian solidarity. Singapore: Didier Millet.

Mapa, D M. 2016. 'O significado das relações sul-sul para a diplomacia Brasileira: a obra de Adolpho Justo Bezerra de Menezes e o pensamento Brasileiro sobre o sul global.' Revista Perspectivas do Desenvolvimento: um enfoque multidimensional 4 (5).

Menezes, A J Bezerra de. 1961. Ásia, África e a política independente do Brasil. Rio de Janeiro: Zahar.

. [1956] 2012. O Brasil e o Mundo Ásio-Africano. Brasília: FUNAG.

1963. Subdesenvolvimento e política internacional. Rio de Janeiro: GRD.

1997. Um diplomata no Oriente/Brasil: subida ou descida para o século XXI? São Paulo: Editora Ágora.

National Writers Association [online]. n.d. 'Adolpho Justo Bezerra de Menezes.' At http://www. anenet.com.br/adolpho-justo-bezerra-de-menezes/ [Accessed on 5 June 2018].

Prado Jr., Caio. 1966. A revolução Brasileira. Brasiliense: São Paulo.

Revel, J. 2009. Proposições: Ensaios de história e historiografia. Rio de Janeiro: EDUERJ.

Rodarte, L. 2018. 'Você se considera ocidental? Para grande parte do mundo, o Brasil não faz parte do Ocidente.' Bol [online]. 24 September. At https://noticias.bol.uol.com.br/ultimas-noticias/internacional/2018/09/24/brasil-nao-e-pais-ocidental.htm?cmpid=copiaecola [Accessed on 16 February 2019].

Rodrigues, J H. 1966. Interesse Nacional e Política Externa. Rio de Janeiro: Civilização Brasileira.

Rosanvallon, P. 2010. Por uma história do político. São Paulo: Alameda.

Rüsen, J. 1996. 'Objetividade e narratividade nas ciências históricas.' História Revista 4 (1): 75-102.

Souza, A J R de. 2011. O orientalismo no (luso) trópico americano: perspectivas Brasileiras sobre a Conferência de Bandung. Niterói: Universidade Federal Fluminense.

Tomich, D. 2011. 'A ordem do tempo histórico: a longue durée e a micro-historia.' Almanack. Guarulhos 2 (2): 38-51.

Vasconcelos, J. 1948. La raza cosmica: misión de la raza iberoamericana, Argentina y Brasil. México: Espasa-Calpe Mexicana.

Vizentini, P G F. 1995. Relações internacionais e desenvolvimento: o nacionalismo e a política externa independente 1951 - 1964. Petrópolis: Vozes. 


\section{About the author}

Marcelo Alves de Paula Lima holds a Bachelor of Arts in History from the Universidade Federal de Minas Gerais, and a Master of Arts in History from the Universidade de São Paulo (FAPESP scholarship). He is currently a Ph.D. student at the Universidade Federal de Minas Gerais (CAPES scholarship). His research is focused on the diplomatic relations between the Brazilian military regime and anti-communist regimes in Asia. He has also been a researcher at the Institute of Contemporary History in Munich (FAPESP international scholarship), and a substitute professor of history at the Universidade Federal de Minas Gerais (2017/2).

\section{História e Engajamento no Trabalho de Bezerra de Menezes}

Resumo: O objetivo deste artigo é analisar os livros escritos por Adolpho Justo Bezerra de Menezes, um dos primeiros diplomatas brasileiros a servir na Indonésia e um grande entusiasta da reaproximação brasileira em relação ao mundo afro-asiático. É notável, em seu discurso, como a interpretação histórica está profundamente ligada ao engajamento político. O autor volta-se para o passado para legitimar um papel maior do Brasil no terceiro mundo. Suas ideias dialogam com o contexto em que foram escritas: expressam a bipolaridade da Guerra Fria e, ao mesmo tempo, defendem mudanças. Muitas das ideias que ele defendia foram posteriormente adotadas pela diplomacia brasileira.

Palavras-chave: Bezerra de Menezes; diplomacia brasileira; política externa independente; não-alinhamento; Guerra Fria; afro-asiática.

Received on 20 September 2018, and approved for publication on 7 June 2019.

(cc) BY-NC https://creativecommons.org/licenses/by-nc/4.0/ 